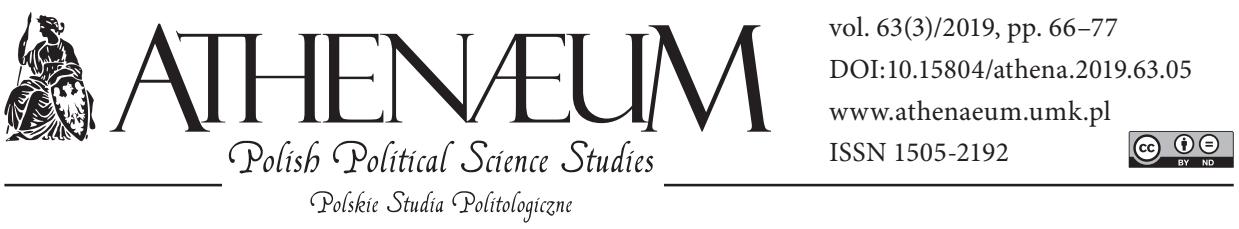

\title{
ELECTORAL OFFICIALS' CORPS: A NEW ELECTORAL APPARATUS
}

\author{
KORPUS URZĘDNIKÓW WYBORCZYCH - \\ NOWY APARAT WYBORCZY
}

Magdalena Wrzalik* $\odot$

\begin{abstract}
The subject of the analysis in the article is a new auxiliary apparatus - the corps of electoral officials. Implemented by the Act of 11 January 2018 on amending certain acts to increase the participation of citizens in the process of selecting, operating and controlling certain public bodies, amendment of the Act of 5 January 2011 - the Electoral Code, introduces this institution. The experience of the local government elections held on October 21, 2018 allows for an initial assessment of the introduced code regulation regarding the new apparatus - the electoral corps. The use of this institution, as a kind of novelty, also allows for the formulation of many detailed proposals of recommendations aimed at eliminating or minimizing the problems and irregularities in the operation of this apparatus, which is the purpose of this scientific article.
\end{abstract}

Keywords: electoral officer; electoral code; electoral apparatus; electoral administration
Przedmiotem analizy przedstawionej w artykule jest nowy aparat pomocniczy - korpus urzędników wyborczych. Dokonana ustawą z dnia 11 stycznia 2018 roku o zmianie niektórych ustaw w celu zwiększenia udziału obywateli w procesie wybierania, funkcjonowania i kontrolowania niektórych organów publicznych nowelizacja ustawy z dnia 5 stycznia 2011 r. - Kodeks wyborczy wprowadza tę instytucję. Doświadczenia z przeprowadzonych 21 października 2018 roku wyborów samorządowych w Polsce pozwalają na wstępną ocenę wprowadzonej regulacji kodeksowej dotyczącej nowego aparatu - korpusu urzędników wyborczych. Zastosowanie tej instytucji, jako swego rodzaju novum, pozwala również na sformułowanie wielu szczegółowych propozycji rekomendacji mających na celu wyeliminowanie bądź zminimalizowanie dostrzeżonych problemów i nieprawidłowości w działaniu pracy tego aparatu, co stanowi cel tego artykułu naukowego.

Słowa kluczowe: urzędnik wyborczy; kodeks wyborczy; aparat wyborczy; administracja wyborcza

* Jan Długosz University in Częstochowa, Faculty of Law and Economics. 
Effectuated by the act of 11 January 2018 on amending certain acts to increase the participation of citizens in the process of selecting, operating and controlling individual public bodies (Dz.U. [Journal of Laws] of 2018 item 130), amendment to the Act of 5 January 2011 - The Electoral Code (consolidated text: Dz.U. [Journal of Laws] of 2018, items 754, 1000, and 1349) introduces a new auxiliary apparatus - the corps of electoral officials. The use of this institution, as a kind of novelty, also allows for the formulation of many detailed proposals for recommendations aimed at eliminating or minimizing the perceived problems and irregularities in the operation of this apparatus. Analyzing this institution, I would like to draw attention to three problems that arose along with its functioning, i.e., recruitment to an electoral officer, insufficient substantive preparation during the training and preparation of electoral logistic officials, and the resulting poor organization of work. It is also worth emphasizing that this solution is not common in other countries, and was introduced in Poland for the first time.

Until January 31, 2018 (in the wording of Article 181 of the Electoral Code), an essential function in the context of ensuring organizational and technical conditions was exercised by electoral officers - proxies for the elections, who were appointed in connection with the tasks of the commune head (mayor, president of city), starost, province marshal (i.e., they concern the preparation of polling stations, including those adapted to the needs of the disabled persons) (Zbieranek, 2018). They were mostly the officials (e.g., municipal offices, cities) who coordinated the implementation of actions related to the election (with a group of other officials to cooperate with) (Zbieranek, 2018). It was also indicated that they should be people who could make decisions, "and hence, are highly placed in the hierarchy of a given office, that they would have a real and not just theoretical impact on the implementation of electoral tasks" (Skotnicki, 2016). Despite the fact that the appointment of an election commissioner was not mandatory, it was, however, a common practice in the activities of local government units. Therefore, this group of several thousand people implemented electoral tasks for many years, having organizational competences in this matter (Sokala, 2010).

Despite fears that were formulated in the course of the Commission's work, the position of an electoral officer was set, as I indicated, in the amendment to the Electoral Code accomplished on January 11, 2018. A new Chapter 9, "Electoral Officials", was introduced in the Code (Art. 191 $\mathrm{a}$ - 191h). Electoral officials are devoted to Art. 191a, wherein $\$ 1$ of this article it is advisable that electoral officers operate in each commune, which is appointed by the Head of the National 
Electoral Office, while $\$ 2$ regulates their position as a corps of electoral officials, in subsequent regulations issues regarding appointment, expiration of functions and scope duties assigned to them. What is more, appointing an office employee as an electoral officer will not be the same as establishing an employment relationship or a civil law contract. According to Art. 154 of the Electoral Code, electoral officials use the legal protection provided for public officials and bear responsibility as public officials. Due to the fact that they are appointed to ensure the proper and smooth functioning of the electoral commissions, it might be worth considering whether it would be correct to call them officers, in this case electoral, ensuring, besides the proper functioning of the electoral commissions, efficient and correct preparation of election process.

\section{PROBLEMS REGARDING THE RECRUITMENT OF ELECTORAL OFFICER}

Election officials following Art. 191c $\$ 1$ of the Electoral Code shall be specified for the area of a given commune in order to ensure correct and efficient functioning of the electoral commissions, giving its listing immediately to the public in a customary manner (Art. 191c $\$ 3$ of the Electoral Code), i.e., by the Delegation Director of the National Electoral Office on the website. In this respect, the resolution of the National Electoral Commission from February 19, 2018 on determining the number, procedure, and conditions for appointing electoral officials, in which the identification number of electoral officers is crucial, accepting as a general rule a conversion rate related to the size - number of occupants. As a consequence to recruitment problems, this ratio has been subject to changes by amending this resolution with subsequent resolutions of the National Electoral Commission of March 12, 2018, March 26, 2018, April 26,2018 . Under the last resolution, it was established that electoral officers were appointed in the number of communes up to 50000 inhabitants - one; up to 200000 inhabitants - two; over 200000 inhabitants - three. About the first case, it may seem incompatible with the literal wording of the provision of Art. 191 a $\$ 1$ of the Electoral Code, in which the plural was indicated by the following statement: "Election officials operate in every municipality". In the subsequent resolutions of the National Electoral Commission of July 23, 2018, as well as the current, on August 13, 2018, determining the number, procedure, and conditions for appointing electoral officials $(\$ 1$ sections 1 and 2 of National Electoral 
Commission Resolution of August 13,2018, on the determination of the number, procedure and conditions for the appointment of electoral officials), the above principles were maintained (Read more: Czaplicki, Dauter, Jaworski, Kisielewicz, Rymarz, Zbieranek, 2018).

Members of the Corps must meet different types of criteria. In order to become an electoral officer, one cannot live or work in a commune in which duties will be carried out - an exception is cities with district rights. This function may not be exercised by a person convicted of an intentional offense prosecuted by public indictment or a fiscal offense belonging to a political party or conducting irreconcilable business activity. A candidate applying for the electoral officer position should submit a report to the delegation director competent for the commune in which one applies for a vacancy. The submission must contain: name(s) and surname, - social security number (PESEL), - address of residence, which is on the electoral register, - information on education and the place of work, - the name of the commune in which the candidate wishes to act as an electoral officer. Persons who have already worked on the organization of elections or have performed other tasks related to the election should include information about their experience in the application. The submission must contain a copy of the diploma confirming the university degree held and the employer confirming the fact of employment in one of the appropriate offices. In practice, however, there is a situation where the fulfilment of so many criteria affects the exclusion of the majority of current, experienced electoral officials. It also affects the efficiency of implementing tasks entrusted to members of the Corps, especially in the context of the coordination of the work of various offices. Observation of the past local elections in 2018 and elections to the European Parliament in May 2019 showed that the most significant organizational problems having a direct impact on work efficiency appeared in the activities related to conducting training for members of the electoral commissions, preparing electoral stations adapted to the needs of disabled voters, printing voting cards and bringing them to individual committees, information activities, performing tasks related to correspondence voting, or information flow between the bodies of the local government unit and the competent delegation.

In the beginning, much controversies and legislative issues arose over already retired electoral officials who, though interested in work on elections, cannot apply for it. The chairman of the National Electoral Commission responded to the allegations raised, arguing that this group of people was deprived of the possibility of performing their functions due to leaving work. He argued that if 
the legislator withdrew from the strict requirement to appoint electoral officers only among the staff of offices servicing government and self-government administration bodies, the corps of elected officials would be considerably larger. Retirees and people derived from, e.g., professional self-government (advocate, counsel applicants), court assistants, etc., would come on board (Śliwińska \& Jaworski, 2018). This aspect, in the subsequent course of the work, was a postulate of legislative changes in the law submitted in the letter of the National Electoral Commission Chairman to the chairman of the local parliamentary committee and regional policy, which was partially reflected in the draft amendment to the marshal's lodge on June 6,2018 . The postulate directly indicated that an electoral official might be not only a person working in the office servicing government bodies, local government bodies or their subordinate or supervised entities, but also one who has at least a five-year seniority in such a place. This allows for interpreting that an electoral officer may be a former administrative employee, including, for example, a pensioner. However, the project promoters did not agree with the previous proposal of the National Electoral Commission Chairman to enable the function of electoral officers to be persons with legal education but without work experience in local government structures.

An electoral official may not run for the electoral district, which includes a commune competent for its area of activity. However, from the regulation, it appears, that an electoral officer can stand as a candidate for election in another district. Article $153 \$ 3$ of the Electoral Code explicitly states that "Electoral officials may not conduct electoral agitation for individual candidates, except for their candidacy". This matter raises major objections and concerns, what is more, it is not a valid solution because it is in an apparent contradiction with the principle of full impartiality of the electoral apparatus.

\section{PROBLEMS ARISING FROM INSUFFICIENT SUBSTANTIVE PREPARATION}

As previously indicated, an electoral officer for the area of a given commune can only be an employee of offices servicing government administration, selfgovernment bodies or subservient units or units supervised by them. A candidate for an electoral officer must also have a university degree. Inherently, this should not raise any interpretation doubts, let alone implementation in electoral practice. The practice of training conducted before the local elections in 2018 and 
the elections to the European Parliament in May 2019, lasting only a few hours (which is worth emphasizing), showed a problem related to the very broadness of the Codex regulation', with which all the officials had to be consulted. During the training, the basic principles of electoral law were also presented, as well as the division into electoral districts or permanent voting circuits. An important conclusion is that for a large group among the training participants, it was a completely new matter because earlier they did not gain experience in organizing and conducting elections/referendums. It showed that the electoral practice $^{2}$, with the implementation of acquired knowledge, appeared even at the roster on the day of the vote, during which doubts arose as to the answers to questions asked by members of individual electoral commissions.

Ignorance of the Code regulations, guidelines of the PKW [National Electoral Commission] directly affects the way work is organized throughout the electoral process at all its stages, which may later cause the need to repeat certain activities and ultimately lead to chaos, affecting the smooth functioning of the electoral commissions. The absence of any substantive requirements about electoral officers themselves, the action-based nature of the measures taken, which is the election and the ineffective training system, affects the quality of the implementation of the duties entrusted. An attempt to minimize such situations could become any changes leading to the introduction of an effective training system. The current regulation that shapes the ongoing social body of electoral officers could, therefore, seem optimal and constitute a sensible solution if the corps were subject to systematic and periodic training (not just directly before the election itself) in the field of electoral law and procedures and the management and organization of committee work. Such training should take place using professional tools and training materials such as e-learning platforms, guidebooks, training videos, interactive exercises, etc. It would be worth considering, whether the training themselves should not be carried out not only by persons with competence in the field of electoral law and procedures but also by social communication. The training system would have to contain a built-in mechanism to check the acquired knowledge, which would help to assess at what level the electoral corps

1 Information obtained from Delegations of the National Electoral Office in cities (Gdańsk, Katowice, Kielce), in which the author of the text conducted training for social observers under the Action. We observe the elections organized by the Stefan Batory Foundation.

2 Conclusions and recommendations taken from the report, which was created thanks to the 2018 social observation carried out during the local government elections, in which over 600 social observers took part, see: Haman, 2018. 
member is ready and what else needs to be improved, what one needs to learn in order to perform its duties effectively, competently and, above all, in accordance with the law. Perhaps it would be worth considering whether or not to make the electoral officer conditional upon obtaining a certain level of knowledge. Unfortunately, such requirements put before electoral officers would have to result in providing a fixed salary, independent of the amount of work performed, which would motivate them to maintain their knowledge at a high substantive level. In contrast, in order to ensure the correctness of the implementation of the duties entrusted during all electoral activities, it would be worth equipping the corps members with transparent and convenient to use checklists or instructors that would work as a "guide" after subsequent tasks, not allowing something to be omitted or made in the wrong order. The current form of the quite extensive guidelines written in a rather difficult language, moreover, not very comfortable to use and not encouraging to get acquainted earlier, certainly does not fulfill this role optimally.

Although the work of an electoral officer means an additional source of income, in practice before the local elections in 2018 and elections to the European Parliament in May 2019, no candidates were willing to perform this function. The deadline for accepting applications for the post of electoral officer in 2018 local elections was shifted twice (read more: Rudziński, 2018). Everything is due to restrictions related to the place of residence, and the code regulation does not provide for reimbursement of travel costs to the commune in which the electoral officer is to operate. The electoral officer for the implementation of statutory tasks is entitled to a remuneration proportional to the time of their implementation, assuming that the remuneration for one month is based on the amount to determine the remuneration of persons holding managerial positions with using a multiplier of 2,5 (Art. 191 $\$$ $\$ 3$ of the Electoral Code). The base amount to determine the remuneration of persons holding managerial positions equals 1789,42 PLN. In this case, the amount of remuneration for an employee's election month should amount to 4473,55 PLN, but only on the assumption that one will perform its tasks on a full monthly basis. It is worth noting that the remuneration is due to the electoral officer for the day on which one performed its tasks, ${ }^{1} /{ }_{20}$ of the amount determined by Art. $191^{\mathrm{e}} \$ 3$ of the Electoral Code, with the reservation that the amount of remuneration may not exceed 4473,55 PLN per one month of work. An official does not have a salary paid for being an official, but one has to account for specific hours (e.g., 4 hours a day) and only receive remuneration for such hours. After the work, the electoral officer should 
present a list which will go to the electoral commissioner who decides whether to approve or reject the said statement. Only the approved statement will result in the payment of appropriate funds to the elector's officer's account.

In duly substantiated cases, due to the scope of the task performed, the election commissioner may decide to increase or decrease the amount determined proportionally, with the reservation that the amount of remuneration may not exceed 4 473,55 PLN per one month's work. However, it should be noted that there may be a situation where the remuneration received will be lower than the remuneration received in the essential place of work. The current regulation does not provide for a mechanism to compensate for this difference, which may also discourage experienced civil servants. The disadvantage of this solution is also the fact that during the period of performing the tasks of an election officer, a given person is not entitled to remuneration in the primary place of work.

The problem which may arise is, how their current employer will accept the additional responsibilities of the members of the corps and how they should adequately combine the electoral officer's function with work in their home office. The Electoral Code stipulates that they will perform their duties periodically, i.e., from the date of ordering the elections until the possible election protests and in other situations where it is necessary. Therefore, the employer is obliged to release an official from work for the duration of his function in the election, but the official should inform him in writing 3 days in advance. Only in emergencies can it be done by phone or email. Unfortunately, the legislator did not conclude explicit employment guarantees in the necessary place of work for a person appointed as an electoral official. In turn, this may result in the fact that, e.g., a local government employee who was on a fixed-term contract during the term of office cannot return afterward. Moreover, there is a concern that no one wants to hire a person who is appointed to an electoral officer, in another office, because it is associated with a lack of availability. Apart from the period, the electoral official performs its duties as a worker in an essential place of work, in which the status is regulated, e.g., by the Act on employees of state offices (consolidated text: Dz.U. [Journal of Laws] of 2017, item 2142, as amended), or the Act on local government employees (consolidated text: Dz.U. [Journal of Laws] of 2016, item 902, as amended). As regards to electoral officers, we are dealing with the case of a temporary secondment of an employee to perform other tasks - on its initiative.

It is also worth considering whether the National Electoral Commission is competent to determine, by way of a resolution, the principle of dismissal from 
work for the duration of the duties of an electoral officer (Czaplicki et al., 2018). It is indicated that all interventions in the legal-worker relationship should be made by way of law or executive regulations. Solely in the law and executive ordinances can one interfere in the rights and freedoms of the citizen, including in legal and employee relations. Therefore, there may be doubts on the side of the employer whether one is obliged to release such a person on principles not regulated in the act or the regulation only by a certificate issued by the election commissioner under the resolution of the National Electoral Commission (Czaplicki et al., 2018).

The last but one concern, which in my opinion should be paid attention to, and whose codex regulation is rather laconic, is the issue of introducing disciplinary provisions. In my estimation, only the practice of these and subsequent elections will be able to show what should be done if the official fails to fulfill its duties. This gives rise to the question of, who should be held responsible for such an electoral officer. In this situation, will the original employer be competent to draw the consequences, considering that he behaved in a disrespectful way to its position. Perhaps disciplinary proceedings and drawing appropriate consequences would not be problematic if these people in the essential place of work would have additional activities related to the organization of elections included in their responsibilities. It should be taken into account that the same person occupying the office of the commune, and electoral officer has two different superiors. According to Art. $191^{\mathrm{d}} \$ 2$ of the Electoral Code, the head of the National Electoral Office has been entitled to dismiss the electoral officer before the expiration of its term in the event of non-performance or improper performance of its duties. Hence, it is possible to derive the obligation of the head of the National Electoral Office to determine the rules of disciplinary proceedings against electoral officers and the right to issue a code of ethics for an electoral officer.

The problem may also arise when the electoral officer gets sick. In this case, considering the need to ensure proper organization of the election, it is necessary to consider who could perform the crucial activities. In the present situation, it could be considered that the National Electoral Commission would entrust the execution of these activities to an electoral officer from another district. Nevertheless, such a possibility should be explicitly provided in the Electoral Code.

The final concern that arouses intensive discussions are the agreements under the authority of the head of the National Electoral Office, which are signed by the directors of the delegations. This process lasted for a relatively long time and raised many doubts about its form. According to the head of the National Elec- 
toral Office, the best solution was to prepare one agreement with such a degree of generality that it could apply to every municipality. Since the head of the National Electoral Office is a one-person apparatus, it would be unrealistic to expect that one will be able to negotiate with each mayor and president in the country-specific terms of agreement. This issue was not taken into account by a rational legislator. Hence it would not be feasible to conclude all agreements, not only for the local elections but also for the upcoming May 2019 election to the European Parliament. According to the head of the National Electoral Bureau (read more: Żółciak, 2018), each municipality is different, and each one implements electoral tasks in a different way. This authority should allow the execution of tasks. At this point, it should be emphasized that cooperation among them is necessary. The wording of Art. 191g of the Election Code clearly shows that the agreements are to concern the technical and organizational-administrative servicing of electoral officers, hence in the agreements, there is no mandatory obligation to divide in detail the tasks of an electoral officer and a commune. Determining the detailed course of action of individual entities that take part in the preparation of the election belongs to the National Electoral Commission, and it is the statutory authority to issue resolutions in this respect. It is worth emphasizing that in the law on the system of education, in Art. 8 Sec. 1 of the Act on municipal self-government (consolidated text: Dz.U. [Journal of Laws] of 2018, item 994), there is a provision that explicitly lists tasks in the organization of preparations and holding general elections and referendums as a state task, distinguishing them from communal tasks entrusted to municipalities.

\section{SUMMATION}

Assessing the institution of the electoral corps is not easy. From a formal point of view, it can be stated that its establishment in 2018 met the expectations of many national environments, that it is the implementation of numerous recommendations and the so-called soft law. It is also undoubtedly a manifestation of the desire to increase the involvement of employees of offices servicing government, self-government administration, and subordinate units and supervised by them in administration control and expressing concern for ensuring fairness and integrity of election procedures and proper implementation of the constitutional principles of this procedure. These are undoubtedly positives proving the needs of the existence of this institution. However, many critical remarks can already be 
made to the regulations in the Electoral Code as regards their precision. One may also wonder whether the criteria for the electoral officer must be appropriately defined and whether it is correct that the electoral officer who is appointed by the head of the National Electoral Office, whose superior is the electoral commissioner, should engage in actions of any electoral committee, let alone stand for election and lead electoral agitation.

However, when assessing the electoral corps, a lot will depend on the practice, and above all on the effectiveness of their work, whether they contribute to the fair conduct of electoral procedures, and most of all the reliability of electoral commission work, which can reduce the possibility of making mistakes or conscious violations of law.

Finally, it is possible to think about whether to properly perform the tasks entrusted to them by the representatives of this corps, at present, it is better to focus on works aimed at creating new training formulas and instructional materials. So that already before the parliamentary elections coming in 2019, more effective care should be taken for better preparation of polling stations for all voters, including, first of all, people with disabilities, implementation of tasks related to correspondence voting, and finally, more efficient functioning of the electoral commissions. Maybe the introduction of improved legal, technical and organizational solutions will contribute to distinguishing among the principles of electoral law the principle of honesty of elections, which the corps of electoral officials can become an extraordinary guarantee.

\section{ReFERENCES:}

Czaplicki, K., Dauter, B., Jaworski, S.J., Kisielewicz, A.Sz., Rymarz, F., \& Zbieranek, J. (eds.). (2018). Kodeks wyborczy. Komentarz ( $2^{\text {nd }}$ Ed.). Warszawa: Wolters Kluwer Polska.

Dz.U. [Journal of Laws] of 2016, item 902, as amended - Ustawa z dnia 10 czerwca 2016 r. o pracownikach samorządowych (Dz.U. z 2016 r., poz. 902 ze zm.).

Dz.U. [Journal of Laws] of 2017, item 2142, as amended - Ustawa z dnia 9 listopada 2017 r. o pracownikach urzędów państwowych (Dz.U. z 2017 r., poz. 2142 ze zm.).

Dz.U. [Journal of Laws] of 2018, item 130 - Ustawa z dnia 11 stycznia 2018 r. o zmianie niektórych ustaw w celu zwiększenia udziału obywateli w procesie wybierania, funkcjonowania i kontrolowania niektórych organów publicznych (Dz.U.z 2018 r., poz. 130).

Dz.U. [Journal of Laws] of 2018, items 754, 1000, and 1349 - Ustawa z dnia 5 stycznia 2011 r. - Kodeks wyborczy (Dz.U. z 2018 r., poz. 754, 1000 i 1349). 
Dz.U. [Journal of Laws] of 2018, item 994 - Ustawa z dnia 8 marca 1990 r. o samorządzie gminnym (Dz.U. z 2018 r., poz. 994).

Haman, J. (2018). Wybory samorzadowe 2018. Raport z obserwacji. Warszawa: Fundacja im. Stefana Batorego. Retrieved from: http://www.batory.org.pl/upload/files/ Programy\%20operacyjne/Masz\%20Glos/ObserwujemyWybory/Wybory\%20 samorzadowe\%202018\%20Raport\%20z\%20badania.pdf.

National Electoral Commission Resolution of August 13, 2018, on the Determination of the Number, Procedure and Conditions for the Appointment of Electoral Officials - Uchwała Państwowej Komisji Wyborczej z dnia 13 sierpnia 2018 r. w sprawie określenia liczby, trybu i warunków powoływania urzędników wyborczych. Retrieved from: https://pkw.gov.pl/pliki_mce/useruploads0/files/uchwa\%C5\%82a_w_sprawie_ liczby_urz\%C4\%99dnik\%C3\%B3w_wyborczych3.pdf.

Rudziński, L. (2018). Wybory samorządowe 2018: PKW ma problem. Urzędnicy nie garna się do obsługi wyborów. Retrieved from: https://polskatimes.pl/wybory-samorzadowe-2018-pkw-ma-problem-urzednicy-nie-garna-sie-do-obslugi-wyborow/ ar/13107979.

Skotnicki, K. (2016). Najistotniejsze zmiany w polskim prawie wyborczym w ostatnim ćwierćwieczu. In: W. Hermeliński, \& B. Tokaj (eds.). 25 lat demokratycznego prawa wyborczego i organów wyborczych w Polsce (1991-2016). Vol. I (pp. 55-65). Warszawa: Krajowe Biuro Wyborcze.

Sokala, A. (2010). Administracja wyborcza w obowiązującym prawie polskim. Toruń: Towarzystwo Naukowe Organizacji I.

Śliwińska, J., \& Jaworski, L. (2018). Chcesz zostać urzędnikiem wyborczym? Zobacz, ile zarobisz i jakie będziesz miał obowiązki. GazetaPrawna.pl. Retrieved from: https://serwisy.gazetaprawna.pl/praca-i-kariera/artykuly/1160260,obowiazki-iwynagrodzenie-urzednika-wyborczego.html.

Zbieranek, J. (2018). Zmiany w Kodeksie wyborczym wprowadzone w styczniu 2018 r. - wybrane problemy. In: E. Żelaska-Makowska, B. Przywora, K. Mucha, M. Wrzalik, (eds.). Aktualne problemy prawa wyborczego. Vol. 2 (pp. 39-59). Częstochowa: Wydawnictwo im. Stanisława Podobińskiego Uniwersytetu HumanistycznoPrzyrodniczego im. Jana Długosza w Częstochowie.

Żółciak, T. (2018). Szefowa KBW o wyborach samorządowych: Samorządy nie uchylą się od wykonania zadania. GazetaPrawna.pl. Retrieved from: https://serwisy. gazetaprawna.pl/samorzad/artykuly/1192695, szefowa-kbw-o-wspolpracy-zsamorzadami-przy-wyborach.html. 